Article

\title{
Research on a Low Melting Point Al-Si-Cu (Ni) Filler Metal for 6063 Aluminum Alloy Brazing
}

\author{
Chengyin Peng ${ }^{1,2}$, Dandan Zhu ${ }^{3}$, Kaifeng Li $^{3}$, Xiang Du ${ }^{1,2}$, Fei Zhao ${ }^{1,2, *}$, Mingpan Wan ${ }^{1,2}$ \\ and Yuanbiao Tan 1,2 \\ 1 College of Materials and Metallurgy, Guizhou University, Guiyang 550025, China; \\ Cheyinpeng@163.com (C.P.); gzuxiangdu@163.com (X.D.); mpwan@gzu.edu.cn (M.W.); \\ ybtan1@gzu.edu.cn (Y.T.) \\ 2 Key Laboratory for Materials Structure and Strength of Guizhou province, Guiyang 550025, China \\ 3 Guizhou Yonghong Heat Transfer \& Cooling Technology Co., Ltd., Huishui 550600, China; \\ zhudd@yonghongcooler.com (D.Z.); Spark.li@yonghongcooler.com (K.L.) \\ * Correspondence: fzhao@gzu.edu.cn; Tel.: +86-139-8488-3791
}

check for updates

Citation: Peng, C.; Zhu, D.; Li, K.; Du, X.; Zhao, F.; Wan, M.; Tan, Y. Research on a Low Melting Point Al-Si-Cu (Ni) Filler Metal for 6063 Aluminum Alloy Brazing. Appl. Sci. 2021, 11, 4296. https://doi.org/ 10.3390/app11094296

Academic Editor: Filippo Berto

Received: 21 April 2021

Accepted: 7 May 2021

Published: 10 May 2021

Publisher's Note: MDPI stays neutral with regard to jurisdictional claims in published maps and institutional affiliations.

Copyright: (c) 2021 by the authors. Licensee MDPI, Basel, Switzerland. This article is an open access article distributed under the terms and conditions of the Creative Commons Attribution (CC BY) license (https:/ / creativecommons.org/licenses/by/ $4.0 /)$.
Featured Application: Research on a Low-Melting-Point Solder for a 6063 Aluminum Alloy Cold Plate Radiator.

Abstract: A new type of low melting point Al-Si-Cu (Ni) filler metal for brazed 6063 aluminum alloy was designed, and the microstructure and properties of the filler metal were systematically studied. The results show that when the content of $\mathrm{Cu}$ in the Al-Si-Cu filler metal increased from $10 \mathrm{wt} . \%$ to $20 \mathrm{wt} . \%$, the liquidus temperature of the filler metal decreased from $587.8^{\circ} \mathrm{C}$ to $533.4{ }^{\circ} \mathrm{C}$. Its microstructures were mainly composed of the $\alpha$-Al phase, a primary $\mathrm{Si}$ phase, and a $\theta\left(\mathrm{Al}_{2} \mathrm{Cu}\right)$ phase. After a proper amount of $\mathrm{Ni}$ was added to the Al-Si-20Cu filler metal, its melting range was narrowed, the spreading wettability was improved, and the microstructure was refined. Its microstructure mainly includes $\alpha$-Al solid solution, Si particles, and $\theta\left(\mathrm{Al}_{2} \mathrm{Cu}\right)$ and $\delta\left(\mathrm{Al}_{3} \mathrm{Ni}_{2}\right)$ intermetallic compounds. The results of the shear strength test indicate that the shear strength of the brazed joint with Al-6.5Si-20Cu-2.0Ni filler metal was $150.4 \mathrm{MPa}$, which was $28.32 \%$ higher than that of the brazed joint with Al-6.5Si-20Cu filler metal.

Keywords: 6063 aluminum alloy; Al-Si-Cu (Ni) filler metals; microstructure; shear strength

\section{Introduction}

Brazing holds the advantages of low deformation of the weldment, high dimensional accuracy, and high production efficiency. Brazing is one of the commonly used connection methods for heat exchangers [1-3]. As a light alloy material with excellent weldability and heat conductivity, 6063 aluminum alloy can be used as the main material of the heat exchanger [4-6]. Al-Si system filler metal is typically used in the brazing of aluminum and its alloys. The content of Si is 7 13 wt.\%, and the liquidus temperature is approximately $570{ }^{\circ} \mathrm{C}[7,8]$. To obtain excellent brazed joints, the brazing temperature must be higher than $595^{\circ} \mathrm{C}$, which is close to the solid phase temperature of 6063 aluminum alloy (approximately $615^{\circ} \mathrm{C}$ ), which may cause base metal grain growth or over-burning [2,4,7]. In addition, an excessive brazing temperature not only enhances the manufacturing cost but also causes dissolution of the base metal, and the quality of the brazed joint obtained is poor [5,9]. Therefore, it is becoming increasingly important to develop a new type of low melting point, aluminum-based filler metal for low-cost and high-quality aluminum alloy brazed joints.

To solve the problem of an excessively high brazing temperature, in recent years, many researchers have developed a series of new low melting point, aluminum-based filler metals by alloying methods with the theoretical support of eutectic components of Al-Si, 
$\mathrm{Al}-\mathrm{Cu}, \mathrm{Al}-\mathrm{Ge}, \mathrm{Al}-\mathrm{Zn}$, etc., and the corresponding properties have been studied [2,7,10-12]. The addition of Ge to the Al-Si filler metal can narrow the melting point of the Al-Si-Ge filler metal, but the melting range of the filler metal will widen with increasing Ge content, and the fluidity of the filler metal will decrease. In addition, Ge is costly; as a result, Al-Si-Ge filler metal is not suitable for large-scale applications [10]. Dai et al. $[8,11]$ studied the Al-6.5Si-42Zn filler metal, the melting range of which was found to be $27.7^{\circ} \mathrm{C}$. When it was used to braze 6061 aluminum alloys, the joint tensile-strength was improved to $129 \mathrm{MPa}$ compared with Al-Si filler metal. However, the content of $\mathrm{Zn}$ in Al-Si-Zn filler metal is too high, which easily causes the dissolution of the base metal and reduces the strength of the brazed joint. Moreover, the vapor pressure of $\mathrm{Zn}$ is too high, which may have adverse effects on the vacuum-brazing process [13]. Al-Si-Cu filler metal has the benefits of a low melting point and good wettability, which is a hot research direction of aluminum alloy filler metals [4,5,7]. Chang et al. [7] studied the brazing of 6061 aluminum alloy with $\mathrm{Al}-10.8 \mathrm{Si}-10 \mathrm{Cu}$ and $\mathrm{Al}-9.6 \mathrm{Si}-20 \mathrm{Cu}$ filler metals at $560{ }^{\circ} \mathrm{C}$, and found that there are more $\theta\left(\mathrm{Al}_{2} \mathrm{Cu}\right)$ brittle phases in the brazed joints, leading to a lower shear strength of the brazed joints (47 MPa and $67 \mathrm{MPa}$, respectively). The results indicate that adding an appropriate amount of $\mathrm{Ni}$ to $\mathrm{Al}-\mathrm{Si}-\mathrm{Cu}$ filler metal can replace part of the $\mathrm{Cu}$ and reduce the adverse effect of $\theta\left(\mathrm{Al}_{2} \mathrm{Cu}\right)$ on joint properties [4,5,14]. Luo et al. [4] developed Al-10Si-15Cu-4Ni filler metal with a melting range of $24.9^{\circ} \mathrm{C}$ and successfully brazed 6061 aluminum alloy at $570{ }^{\circ} \mathrm{C}$. Meanwhile, the joint shear strength was as high as $144.4 \mathrm{MPa}$, which was higher than that of Al-Si-Cu brazing filler metal [2,7]. However, Al-Si-Cu filler metal still has the problems of a wide melting interval and a low shear strength of the brazed joint, which urgently needs to be solved.

Based on the pseudoeutectic point composition of Al-Si-Cu ternaries [15], a new type of Al-Si-Cu (Ni) multicomponent aluminum-based filler metal with a low melting point and a narrow melting interval was developed. The optimal Al-Si-Cu (Ni) filler metal was obtained by a comprehensive analysis after studying the melting characteristics, the spreading wettability, the microstructure, and the brazeability of different $\mathrm{Al}-\mathrm{Si}-\mathrm{Cu}(\mathrm{Ni})$ filler metals. Its properties have been significantly improved compared with those of existing filler metals.

\section{Materials and Methods}

The base material used in this experiment was 6063 aluminum alloy plates with a thickness of $1 \mathrm{~mm}$. Its chemical composition is listed in Table 1 . The melting temperature of the base metal was approximately $617.8 \sim 657.7^{\circ} \mathrm{C}$, and the tensile strength at room temperature was $257.94 \mathrm{MPa}$. A series of Al-Si-Cu and Al-Si-Cu-Ni filler metals were prepared using the master alloys Al-50Cu ( $\geq 99.970 \mathrm{wt} . \%), \mathrm{Al}-30 \mathrm{Si}$ ( $\geq 99.970 \mathrm{wt} . \%)$, and $\mathrm{Al}-10 \mathrm{Ni}(\geq 99.000$ wt.\%) and high-purity aluminum particles ( $\geq 99.900 \mathrm{wt} . \%)$ as raw materials, which were melted in a well-type resistance furnace covered with molten salt with a mass ratio of $\mathrm{NaCl}: \mathrm{KCl}=1: 1$. Hexachloroethane was used the refining agent. The nominal compositions of the investigated filler metal are listed in Table 2. To ensure the compositional uniformity of the brazing alloys, each group was remelted twice, and the obtained castings were heat-retained at $450{ }^{\circ} \mathrm{C}$ for $12 \mathrm{~h}$ for the diffusion annealing treatment.

Table 1. Chemical composition (wt.\%) of 6063 aluminum alloy.

\begin{tabular}{cccccccccc}
\hline Alloy & Si & Mg & Fe & Cu & Mn & Cr & Zn & Ti & Al \\
\hline 6063 & 0.462 & 0.603 & 0.173 & 0.016 & 0.018 & 0.006 & 0.005 & 0.053 & Bal. \\
\hline
\end{tabular}

The melting temperature of the filler metal was determined by differential thermal analysis (DTA, TG/DTA7300, Japan). The filler metal was heated from room temperature to $700{ }^{\circ} \mathrm{C}$ under an argon atmosphere at a heating rate of $10{ }^{\circ} \mathrm{C} / \mathrm{min}$. The fluidity and wettability of filler metals were assessed by wetting experiments. After the filler metals with a size of $3 \mathrm{~mm} \times 3 \mathrm{~mm} \times 3 \mathrm{~mm}$ were weighed, they were placed at the center of the 
base material 6063 aluminum alloy $(40 \mathrm{~mm} \times 40 \mathrm{~mm} \times 1 \mathrm{~mm})$ and completely covered with QJ201 flux (with a melting range of $460 \sim 520^{\circ} \mathrm{C}$ ) (Figure 1). The process parameter of the spreading test was $570 \pm 3^{\circ} \mathrm{C}$ for $5 \mathrm{~min}$. The spread sample was washed with warm water $\left(50 \sim 60^{\circ} \mathrm{C}\right)$, photographed with a camera, and imported into Image-Pro Plus to measure the spreading area of the filler metals. The results were averaged by the spreading area per unit mass.

Table 2. Nominal chemical compositions and thermal properties of the filler metals used in this study.

\begin{tabular}{|c|c|c|c|c|c|c|c|}
\hline \multirow{2}{*}{ Samples } & \multicolumn{4}{|c|}{ Chemical Compositions (wt.\%) } & \multirow{2}{*}{$T_{S}\left({ }^{\circ} \mathrm{C}\right)$} & \multirow{2}{*}{$T_{L}\left({ }^{\circ} \mathrm{C}\right)$} & \multirow{2}{*}{$\Delta T\left({ }^{\circ} \mathrm{C}\right)$} \\
\hline & Si & $\mathrm{Cu}$ & $\mathrm{Ni}$ & Al & & & \\
\hline 1 & 6.5 & 10 & 0 & Bal. & 521.3 & 587.8 & 66.5 \\
\hline 2 & 6.5 & 15 & 0 & Bal. & 521.6 & 539.7 & 18.1 \\
\hline 3 & 6.5 & 20 & 0 & Bal. & 521.4 & 533.4 & 12.0 \\
\hline 4 & 6.5 & 20 & 1.0 & Bal. & 519.8 & 528.4 & 8.6 \\
\hline 5 & 6.5 & 20 & 1.5 & Bal. & 520.5 & 528.2 & 7.7 \\
\hline 6 & 6.5 & 20 & 2.0 & Bal. & 519.2 & 526.8 & 7.6 \\
\hline
\end{tabular}

$T_{S}$ indicates the solidus temperatures of the filler metals. $T_{L}$ indicates the liquidus temperatures of the filler metals. $\Delta T$ indicates the melting ranges of the filler metals $\left(\Delta T=T_{L}-T_{S}\right)$.

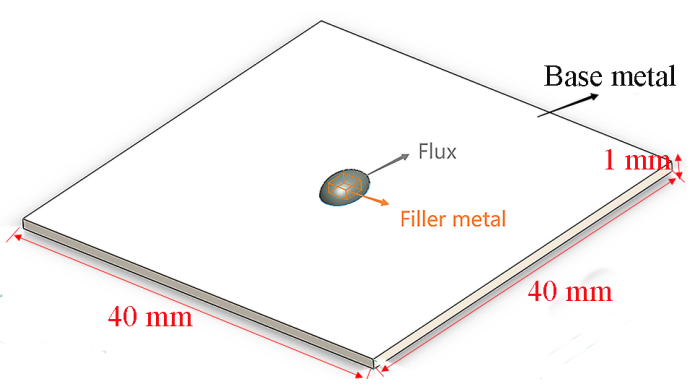

Figure 1. Schematic illustration of the spreading testing.

The brazing experiment was completed in a box-type resistance furnace. A schematic illustration of the brazed joint is shown in Figure 2. The specification of the base material was $50 \mathrm{~mm} \times 20 \mathrm{~mm} \times 1 \mathrm{~mm}$, the specification of the filler metal was $15 \mathrm{~mm} \times 1 \mathrm{~mm} \times 0.2 \mathrm{~mm}$, the lap length of the joint was $1.5 \mathrm{~mm} \pm 0.3 \mathrm{~mm}$, the gap was $0.1 \pm 0.05 \mathrm{~mm}$, and the flux used for brazing was QJ201. Before brazing, the surface of the base metal and the filler metal was polished with sandpaper. After the acetone was degreased, the surface oxide film was removed with a $10 \% \mathrm{NaOH}$ solution and then neutralized with a $10 \%$ $\mathrm{HNO}_{3}$ solution. Finally, the samples were cleaned with ethanol, dried, and assembled. The brazing technological parameters were as follows: raise the furnace temperature to $570{ }^{\circ} \mathrm{C}$, put the prepared sample into the furnace after the furnace temperature becomes stable, keep the temperature at $570{ }^{\circ} \mathrm{C}$ for $10 \mathrm{~min}$, stop heating, open the furnace door to take out the sample for air cooling when the furnace temperature drops to approximately $500{ }^{\circ} \mathrm{C}$, and finally clean the sample repeatedly with hot water $\left(50 \sim 60^{\circ} \mathrm{C}\right)$ to remove the flux residue. Two step-aging treatments were adopted to improve the mechanical properties of the brazed parts. The heat treatment system was as follows: after solid solution treatment $\left(530^{\circ} \mathrm{C} \times 3 \mathrm{~h}\right)$ and room temperature water quenching of the brazed parts, the brazed parts were immediately subjected to primary aging $\left(160^{\circ} \mathrm{C} \times 1 \mathrm{~h}\right)$ and water cooling, Finally, the brazed parts were subjected to secondary aging for $3 \mathrm{~h}$ at $190^{\circ} \mathrm{C}$ and water cooling. 


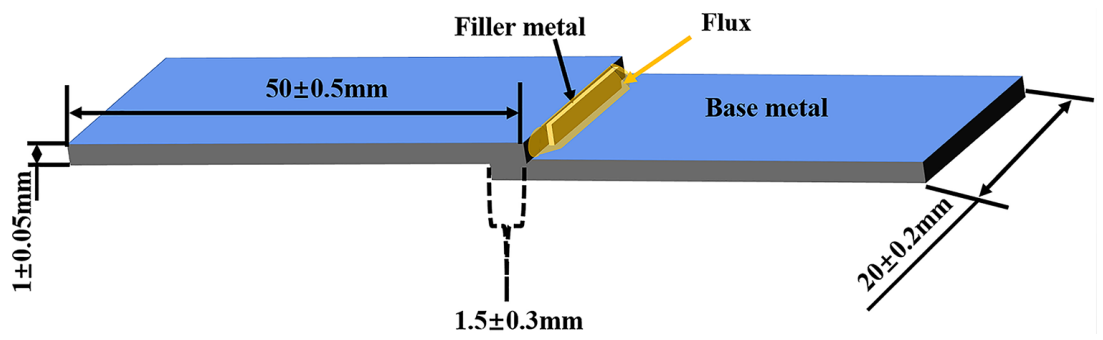

Figure 2. Schematic illustration of the spreading testing.

The microstructures of the filler metals were analyzed by an X-ray diffractometer (XRD, $\mathrm{Cu} \mathrm{K} \alpha$, Empyrean, Holland). The scanning angle was $10^{\circ}$ to $90^{\circ}$, the scanning rate was $0.188^{\circ} / \mathrm{s}$, the accelerating voltage was $45 \mathrm{kV}$, and the working current was $40 \mathrm{~mA}$. The shear strength of a brazed joint was measured on an Instron 8501 universal testing machine at a tensile speed of $0.5 \mathrm{~mm} / \mathrm{min}$. To ensure the accuracy of the results on the shear strength of the brazed joints, three specimens were brazed under the same conditions with each filler metal, and the average values of the test results were calculated. The microVickers hardness of brazed joints was measured by an MHV-2.0 automatic microhardness tester, three points were measured in each area, and the average value of the results was taken. Scanning electron microscopy (SEM. SUPRA 40, Germany) and energy dispersive spectrometry (EDS) were used to observe the microstructure of the filler metals and brazed joints after etched in a mixture of 1 vol. $\% \mathrm{HF}, 1.5$ vol. $\% \mathrm{HCl}, 2.5 \mathrm{vol} . \% \mathrm{HNO}_{3}$ and 95 vol.\% $\mathrm{H}_{2} \mathrm{O}$ at room temperature for $20 \mathrm{~s}$.

\section{Results and Discussion}

\subsection{Melting Characteristics of the Al-Si-Cu (Ni) Filler Metal}

Figure 3 shows the melting characteristics of filler metals with different $\mathrm{Cu}$ and Ni contents. The melting temperatures of the filler metals in this study, determined according to the DTA curve in Figure 3, are summarized in Table 2. Combined with Table 2 and the Figure 3 analysis, when the $\mathrm{Cu}$ content was reduced from 10 wt.\% to $20 \mathrm{wt} . \%$, the liquidus temperatures of Al-Si-Cu alloys decreased from $587.8^{\circ} \mathrm{C}$ to $533.4^{\circ} \mathrm{C}$, the solidus temperature had no significant effects, and the melting temperature ranges of Al-6.5Si- $(10,15,20) \mathrm{Cu}$ filler metals gradually became narrower $\left(66.5{ }^{\circ} \mathrm{C}, 18.1{ }^{\circ} \mathrm{C}\right.$, and $12.0^{\circ} \mathrm{C}$, respectively). With increasing $\mathrm{Cu}$ content, the composition of the Al-Si-Cu filler metal gradually approached the eutectic composition point of the Al-Si-Cu ternary alloy, noncongruent melting gradually changed into congruent melting, thus reducing the melting temperature range [15]. It can be seen from Figure 3 that the DTA curve of the Al-6.5Si-10Cu filler metal was similar to that in previous research [4,7]; it was not a single endothermic peak but a certain number of endothermic peaks, and the corresponding temperatures were a: $528.5^{\circ} \mathrm{C}, \mathrm{b}: 552.4^{\circ} \mathrm{C}$, and c: $587.8^{\circ} \mathrm{C}$. According to the Al-Si-Cu, $\mathrm{Al}-\mathrm{Cu}$, and Al-Si phase diagram [16-18], it was inferred that endothermic peak a was related to the reverse reaction of the $\mathrm{L} \rightarrow \alpha(\mathrm{Al})+\mathrm{Si}+\theta\left(\mathrm{Al}_{2} \mathrm{Cu}\right)$ reaction, and endothermic peaks $b$ and $c$ were relatively smooth, which was presumed to be related to the Al-Cu eutectic and Al-Si eutectic reactions.

When $1.0 \mathrm{wt} . \%, 1.5 \mathrm{wt} . \%$, and $2.0 \mathrm{wt} . \% \mathrm{Ni}$ were added to the ternary filler metal Al$6.5 \mathrm{Si}-20 \mathrm{Cu}$, the solidus temperatures of the filler metals did not change obviously, but the liquidus temperature was somewhat reduced. The solidus and liquidus temperatures of the Al-Si-Cu-Ni alloys were $519.8 \sim 528.4{ }^{\circ} \mathrm{C}, 520.8 \sim 528.2{ }^{\circ} \mathrm{C}$, and $519.2 \sim 526.8^{\circ} \mathrm{C}$, respectively. Because the addition of $\mathrm{Ni}$ introduces a novel low melting temperature alloy reaction, the reverse reaction of $\mathrm{L} \rightarrow \alpha(\mathrm{Al})+\mathrm{Si}$ was inhibited, and the liquidus temperature of the brazing alloy was reduced [18]. The composition of the Al-6.5Si-20Cu-2.0Ni filler metal was close to the eutectic point of the Al-Si-Cu-Ni quaternary alloy, so the DTA curve of the filler metal was relatively gentle between 526.8 and $530.1{ }^{\circ} \mathrm{C}[4,15,19]$, and the melting temperature range of Al-Si-Cu-Ni filler metals was narrower than that of Al-Si$\mathrm{Cu}$. Compared with previous scholars' research on Al-10Si-15Cu-4Ni( $\left.\Delta \mathrm{T}=24.9{ }^{\circ} \mathrm{C}\right)[4]$, 
Al-8.5Si-25Cu-1.5Ni-0.2Re $\left(\Delta \mathrm{T}=18.0^{\circ} \mathrm{C}\right)[5], \mathrm{Al}-10.8 \mathrm{Si}-10 \mathrm{Ge}\left(\Delta \mathrm{T}=61.0^{\circ} \mathrm{C}\right)[10]$ and Al6.5Si-42Zn-Sr $\left(\Delta \mathrm{T}=28.1^{\circ} \mathrm{C}\right)$ [11], the melting temperature ranges of the $\mathrm{Al}-6.5 \mathrm{Si}-20 \mathrm{Cu}$, and Al-6.5Si-20Cu-(1.0, 1.5, 2.0) Ni filler metals were narrower, which will facilitate the filling of the joint gaps with the liquid filler metals during the brazing process $[4,20]$.
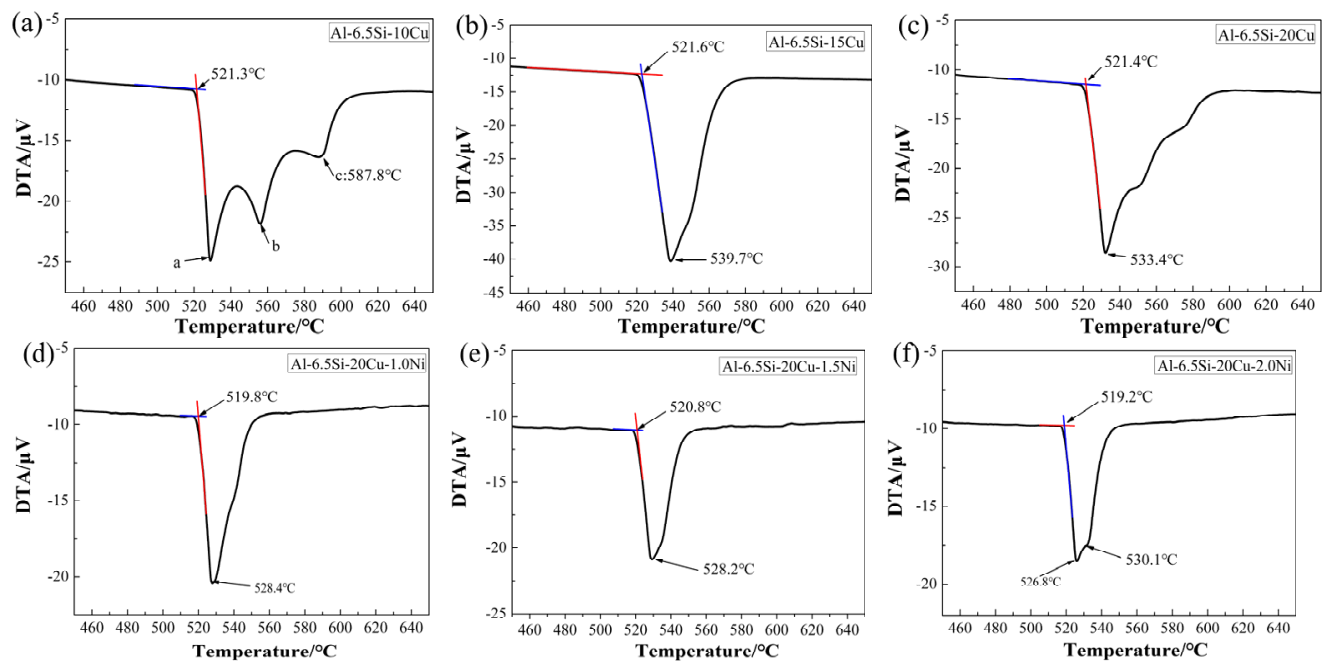

Figure 3. DTA curves of the (a) Al-6.5Si-10Cu, (b) Al-6.5Si-15Cu, (c) Al-6.5Si-20Cu, (d) Al-6.5Si-20Cu$1.0 \mathrm{Ni}$, (e) Al-6.5Si-20Cu-1.5Ni, and (f) Al-6.5Si-20Cu-2.0Ni filler metals.

\subsection{Effect of $\mathrm{Cu}$ and Ni on the Microstructure of Al-Si-Cu (Ni) Filler Metals}

The microstructures of the filler metals were analyzed by SEM, XRD, and EDS. Figure 4 shows the XRD patterns of Al-Si-Cu alloys and Al-Si-Cu-Ni alloys. The XRD results show that the Al-6.5Si- $(10,15,20) \mathrm{Cu}$ were mainly composed of the $\alpha$-Al phase, a Si phase, and a $\theta\left(\mathrm{Al}_{2} \mathrm{Cu}\right)$ phase. The Al-6.5Si-20Cu-(1.0, 1.5, 2.0) Ni were mainly composed of the $\alpha-\mathrm{Al}$ phase, a $\mathrm{Si}$ phase, a $\theta\left(\mathrm{Al}_{2} \mathrm{Cu}\right)$ phase, and $\delta-\mathrm{Al}_{3} \mathrm{CuNi}\left(\mathrm{Al}_{3} \mathrm{Ni}_{2}\right)$.
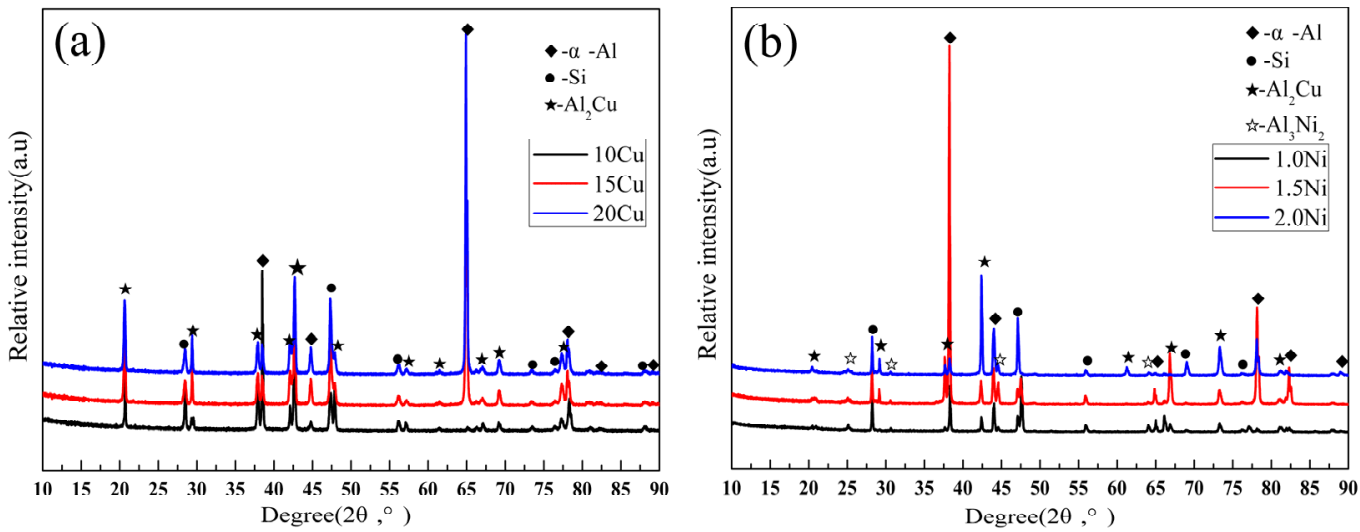

Figure 4. XRD patterns of the (a) Al-Si-Cu and (b) Al-Si-Cu-Ni filler metals.

Figure 5 shows the SEM images of the filler metals. Figure $5 a-c$ indicates that the Al-6.5Si- $(10,15,20) \mathrm{Cu}$ filler metals are composed of the $\alpha$-Al solid solution phase, bulk primary $\mathrm{Si}$, and a $\theta\left(\mathrm{Al}_{2} \mathrm{Cu}\right)$ intermetallic compound. With increasing $\mathrm{Cu}$ content, the number of $\theta\left(\mathrm{Al}_{2} \mathrm{Cu}\right)$ phases gradually increases, and the size gradually increases. According to Figure $5 \mathrm{~d}-\mathrm{f}$, the Al-6.5Si-20Cu-(1.0, 1.5, 2.0) Ni filler metals had reticular structure, and the reticular solid solution phase was the $\delta\left(\mathrm{Al}_{3} \mathrm{Ni}_{2}\right)$ phase according to the EDS analysis and XRD patterns [21,22]. With increasing Ni content, the number of bulk primary Si phases decreased, part of the Si phase was refined, showing a fibrous structure, and the brittle $\theta\left(\mathrm{Al}_{2} \mathrm{Cu}\right)$ phase gradually transformed from a bulk to a lamellar-type structure, as shown in Figure 5d-e. 

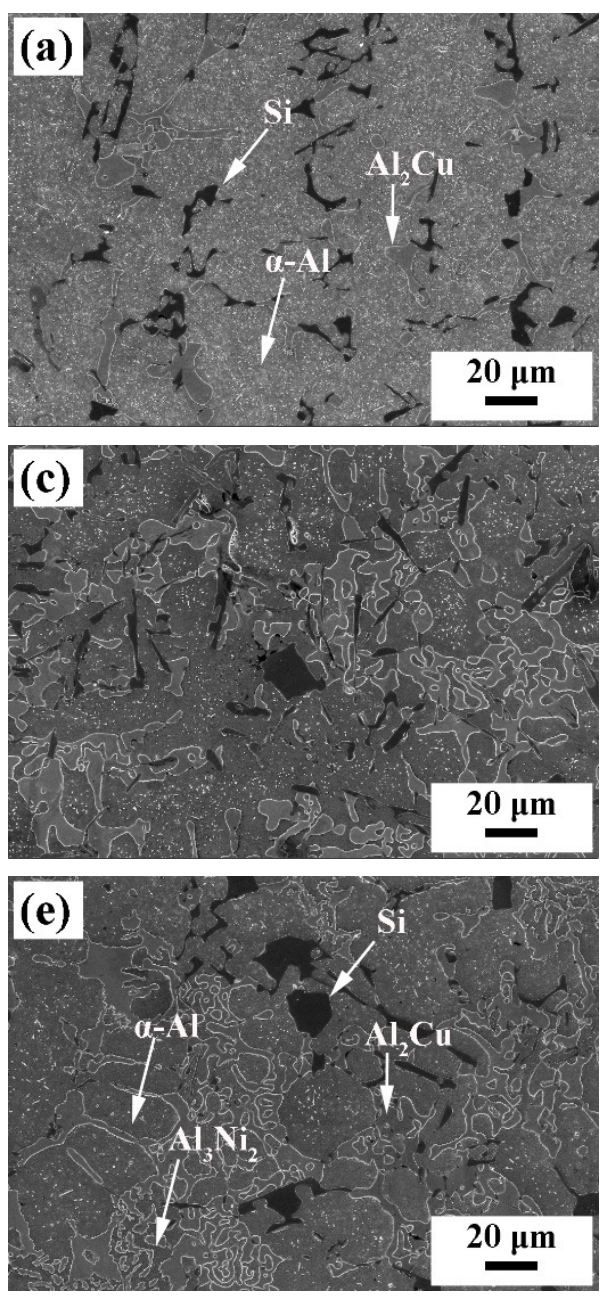
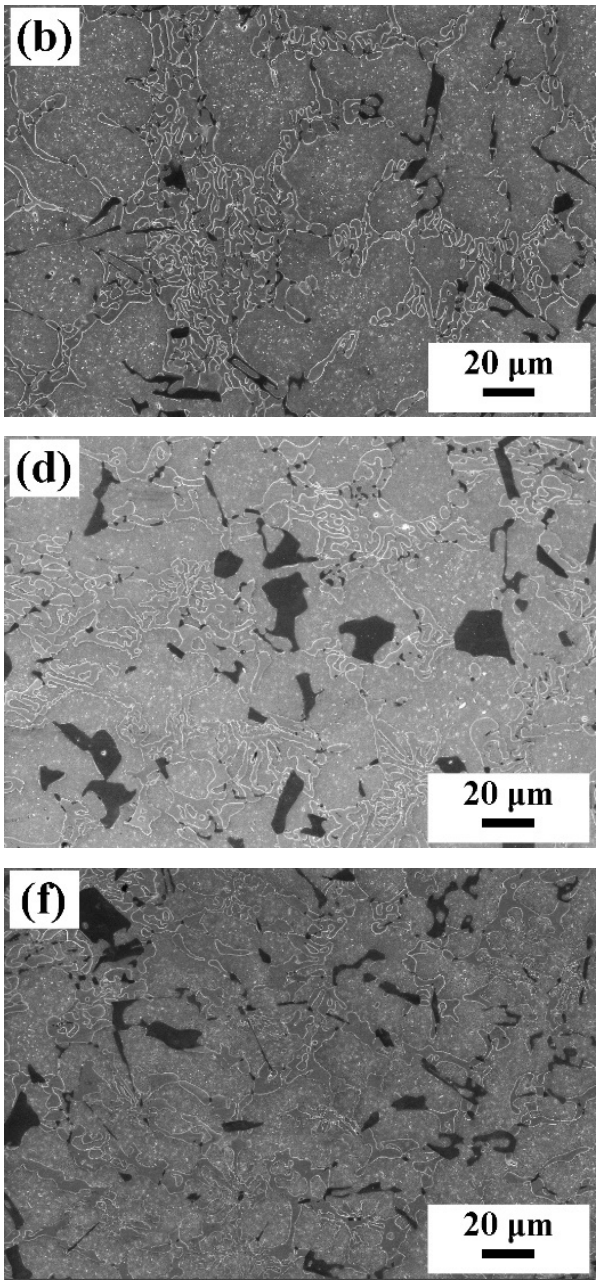

Figure 5. Microstructures of the (a) Al-6.5Si-10Cu, (b) Al-6.5Si-15Cu, (c) Al-6.5Si-20Cu, (d) Al-6.5Si20Cu-1.0Ni, (e) Al-6.5Si-20Cu-1.5Ni, and (f) Al-6.5Si-20Cu-2.0Ni filler metals.

To further analyze the elemental distribution of the filler metals and the influence of $\mathrm{Ni}$ on the microstructure of the Al-Si-Cu filler metals, an EDS surface scanning analysis was carried out on the microstructures of the Al-6.5Si-20 Cu and Al-6.5Si-20Cu-1.5Ni filler metals. The EDS element mapping are shown in Figure 6, and the EDS results are shown in Table 3. The EDS analysis showed that $A$ and $G$ were mainly Si phases, $C$ and $E$ were mainly $\alpha$-Al phases, $\mathrm{B}$ and $\mathrm{D}$ were mainly $\mathrm{Al}_{2} \mathrm{Cu}$ phases, and $\mathrm{F}$ was mainly a $\delta\left(\mathrm{Al}_{3} \mathrm{Ni}_{2}\right)$ phase. The element distribution diagram indicates that part of the $\mathrm{Si}$ phase was embedded in the $\alpha$-Al phase, and part of the $\mathrm{Cu}$ was replaced by $\mathrm{Ni}$ in the $\theta\left(\mathrm{Al}_{2} \mathrm{Cu}\right)$ phase region, causing the local intermetallic compound $\theta\left(\mathrm{Al}_{2} \mathrm{Cu}\right)$ to change from elongated to discontinuous. The blade shape can effectively reduce the adverse effect of the intermetallic compound $\theta\left(\mathrm{Al}_{2} \mathrm{Cu}\right)$ on the solder alloy. 

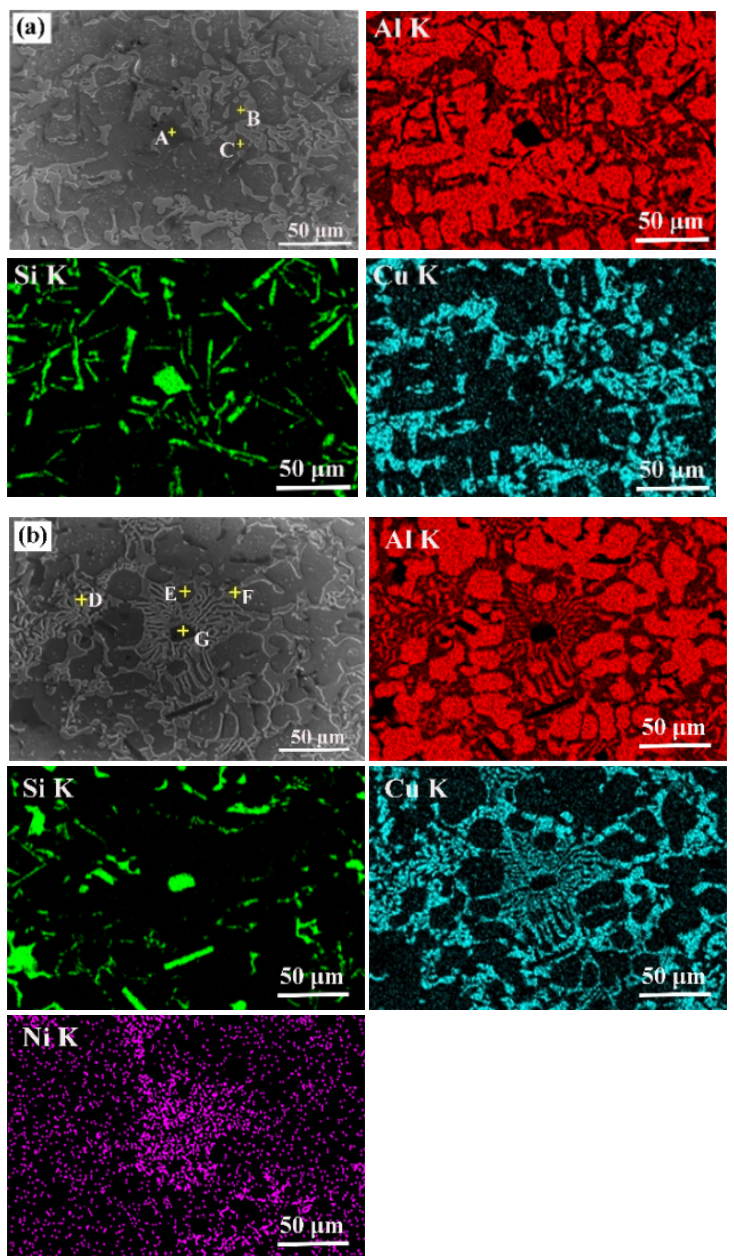

Figure 6. EDS element mapping of microstructures of the (a) Al-6.5Si-20Cu and (b) Al-6.5Si-20Cu$1.5 \mathrm{Ni}$ filler metals.

Table 3. EDS results on the chemical composition (wt.\%) of points marked in Figure 6.

\begin{tabular}{ccccc}
\hline Testing Points & Al & Si & Cu & Ni \\
\hline A & 1.05 & 98.88 & 0.06 & 0 \\
B & 42.20 & 0.23 & 57.57 & 0 \\
C & 96.41 & 0.21 & 3.38 & 0 \\
D & 41.63 & 0.06 & 57.18 & 0.82 \\
E & 95.87 & 0.47 & 3.34 & 0.31 \\
F & 37.47 & 0.12 & 52.64 & 9.78 \\
G & 1.06 & 98.26 & 0.31 & 0.38 \\
\hline
\end{tabular}

\subsection{Wettability of Al-Si-Cu (Ni) Filler Metal on Substrates}

The fluidity of the filler metal was one of the factors affecting the quality of brazed joints, and the spreading area of the brazing alloy on the base material can well reflect the wetting and flowing joint-filling ability of brazing filler metal. The effects of different $\mathrm{Cu}$ and $\mathrm{Ni}$ contents on the spreading properties of the Al-Si-Cu and Ni filler metals are shown in Table 4. The spreading area per unit mass of Al-Si- $(10,15,20) \mathrm{Cu}$ filler metals increased from $0.58 \mathrm{~cm}^{2}$ to $2.87 \mathrm{~cm}^{2}$. Compared with the Al-6.5Si-20Cu filler metal, the spreading area per unit mass of Al-6.5Si-20Cu- $(1.0,1.5,2.0)$ Ni filler metals increased by $12.5 \%, 8.0 \%$, and $6.8 \%$, respectively. When $2.0 \mathrm{wt} . \% \mathrm{Ni}$ was added, the liquidus temperature of the filler metal increased, the melting range became wider, and the spreading ability decreased, 
which may be due to the formation of more complex alloy compounds between $\mathrm{Ni}$ and $\mathrm{Al}$, which affected the fluidity of the filler metal [21-23].

Table 4. Analysis of the spreading properties of the filler metals.

\begin{tabular}{cc}
\hline Filler Metals & Spread Area per Unit Mass $\left(\mathbf{c m}^{2} / \mathbf{g}\right)$ \\
\hline Al-6.5Si-10Cu & 0.58 \\
Al-6.5Si-15Cu & 1.71 \\
Al-6.5Si-20Cu & 2.87 \\
Al-6.5Si-20Cu-1.0Ni & 3.28 \\
Al-6.5Si-20Cu-1.5Ni & 3.12 \\
Al-6.5Si-20Cu-2.0Ni & 3.08 \\
\hline
\end{tabular}

Figure 7 shows the microstructures of the spreading interface of the $\mathrm{Al}-6.5 \mathrm{Si}-20 \mathrm{Cu} / \mathrm{base}$ material and the Al-6.5Si-20Cu-1.5Ni/base material. According to Fick's law of diffusion, there was a large concentration difference between the filler metal and the base metal; therefore, $\mathrm{Cu}$ in the filler metal diffused into the base metal along the grain boundaries and reacted with $\mathrm{Al}$ in the base material to form $\theta\left(\mathrm{Al}_{2} \mathrm{Cu}\right)$ intermetallic compounds. The base materials interlaced with each other at the spreading interface, forming a diffusion layer between the filler metal and the base material. The microstructures of the spreading interface in Figure 7c,d were analyzed by EDS, and the results are shown in Table 5 and Figure 8. Table 5 shows that the microstructure of the Al-6.5Si-20Cu filler metal/ $\mathrm{Al}$ spreading interface was mainly composed of three phases: the $\alpha-\mathrm{Al}$ phase, a $\theta\left(\mathrm{Al}_{2} \mathrm{Cu}\right)$ phase, and a Si phase. Figure 8 shows that $\mathrm{Ni}$ replaced a certain amount of $\mathrm{Cu}$ in the microstructure of the Al-6.5Si-20 Cu-1.5Ni filler metal/ $\mathrm{Al}$ spreading interface such that the $\mathrm{Cu}$ and $\mathrm{Ni}$ are interlaced, which weakened the influence of $\mathrm{Cu}$ on the brittleness of the brazed alloys. Therefore, the addition of $\mathrm{Ni}$ can not only advance the interdiffusion of elements between the filler metal and the base metal, but also refine the grains and improve the performance of the filler metal.
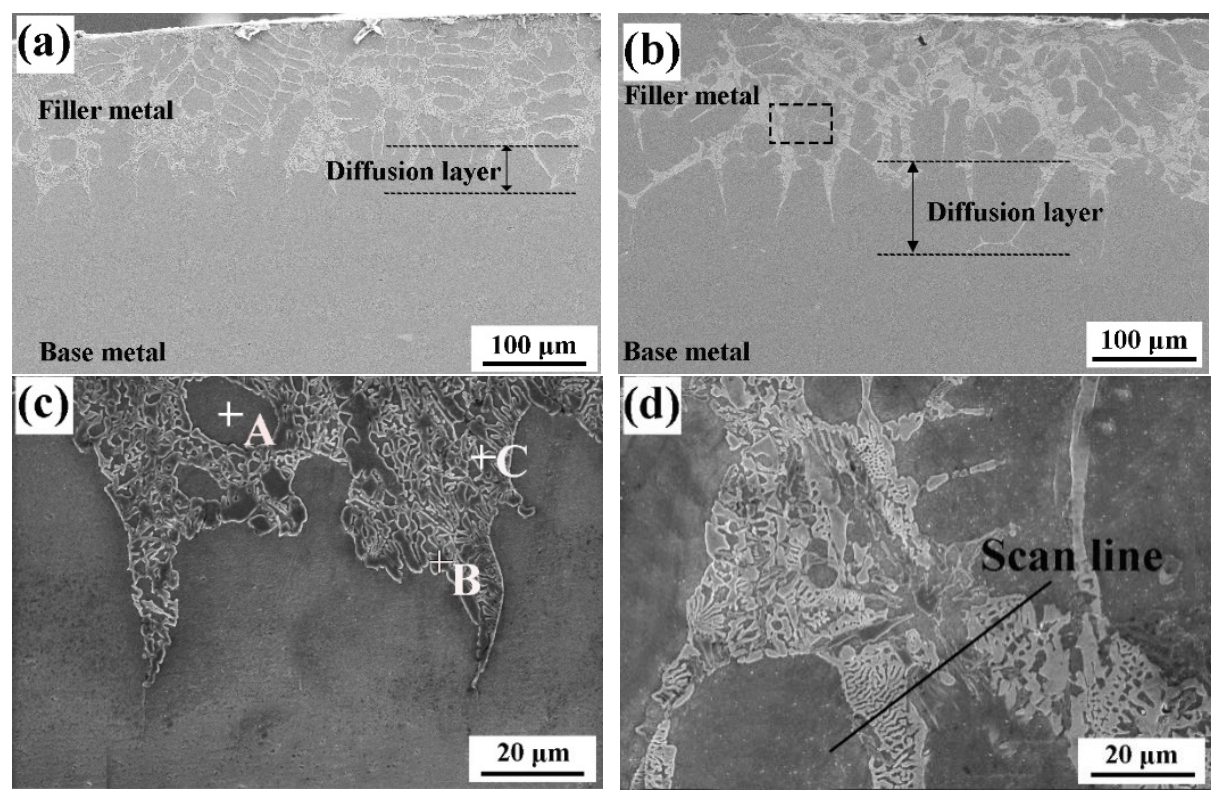

Figure 7. Microstructures of the spreading interface of the Al-6.5Si-20 Cu $(\mathbf{a}, \mathbf{c})$ and $\mathrm{Al}-6.5 \mathrm{Si}-20 \mathrm{Cu}-1.5 \mathrm{Ni}$ $(\mathbf{b}, \mathbf{d})$ filler metal. 
Table 5. Chemical composition (wt.\%) of the points in Figure 7c.

\begin{tabular}{cccc}
\hline Testing Points & Al & Si & Cu \\
\hline A & 90.27 & 1.70 & 8.03 \\
B & 40.36 & 1.15 & 58.49 \\
C & 51.06 & 6.77 & 42.17 \\
\hline
\end{tabular}
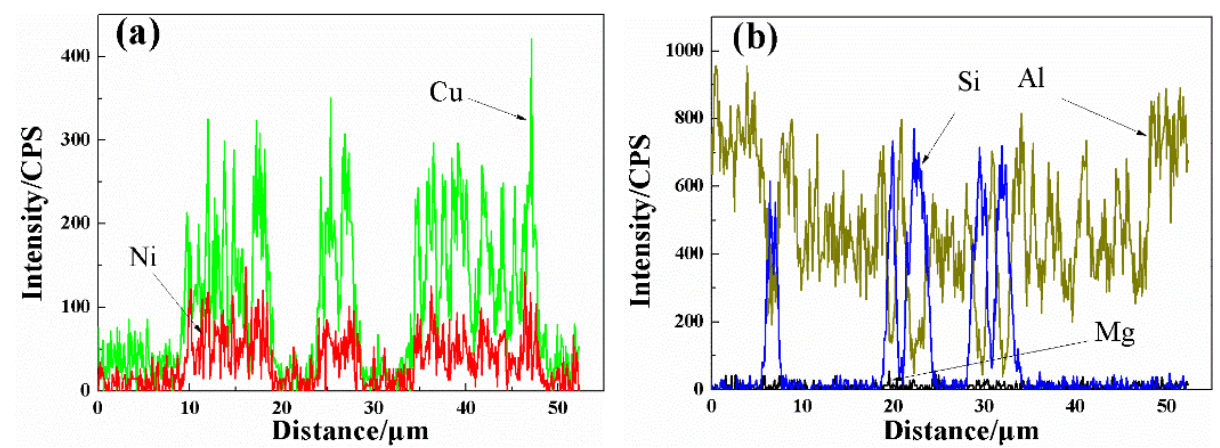

Figure 8. Line-EDS analysis of the spreading interface in Figure 7d: (a) Cu, Ni elements; (b) Al, Si, Mg elements.

\subsection{Brazeability of 6063 Aluminum Alloy with Al-Si-Cu (Ni) Filler Metal}

Figure 9 shows the microstructure of the aluminum alloy brazed joints after heat treatment strengthening. The microstructures of the brazed joints were compact and showed good metallurgical bonding. Table 6 shows the results of the EDS analysis of the six points marked in Figure 9a,c. It can be concluded that the microstructure of the Al6.5Si-20Cu brazed joint was mainly composed of the $\alpha$-Al phase, a coarse $\theta\left(\mathrm{Al}_{2} \mathrm{Cu}\right)$ phase, and a Si phase. There was a small amount of $\mathrm{Al}_{2} \mathrm{Cu}$ intermetallic compound at the brazed joint interface, and some Si particles were embedded in the matrix [14,24]. Figure $9 \mathrm{~b}-\mathrm{d}$ show the microstructure diagrams of Al-6.5Si-20Cu-Ni brazed joints. The addition of $\mathrm{Ni}$ produces the $\delta\left(\mathrm{Al}_{3} \mathrm{Ni}_{2}\right)$ phase, which makes the $\mathrm{Al}_{2} \mathrm{Cu}$ at the brazing seams transition from a bulk to a lamellar-type structure, and the microstructure distribution of the joints is more monotonous. Figure 10 shows the line scan distribution diagram of the elements in Figure 9a. In the brazing process, $\mathrm{Cu}$ and $\mathrm{Si}$ were enriched at the interface between the brazing seam and the base metal, and the post-welding heat treatment promoted the interdiffusion between atoms, so the contents of $\mathrm{Al}$ and $\mathrm{Mg}$ at the interface of the brazing seam were significantly reduced $[4,11]$. Figure 11 shows a schematic diagram of the surface scanning consequences of the microstructure of Al-6.5Si-20Cu-1.5Ni-brazed 6063 aluminum alloy joints. $\mathrm{Cu}$ and $\mathrm{Ni}$ were uniformly distributed in the central area of the brazing seams, the segregation of $\mathrm{Si}$ was reduced, which was conducive to reducing the Si phase, and the $\theta\left(\mathrm{Al}_{2} \mathrm{Cu}\right)$ phase influenced the brittleness of the brazed joints. The results of the EDS analysis (Table 6) show that the $\mathrm{Si}$ and $\mathrm{Cu}$ contents at $\mathrm{B}$ and $\mathrm{F}$ were higher than those of the base material at the joint interface, which indicates that during the brazing process of Al-Si-Cu (Ni) filler metals and 6063 aluminum alloy, the elements between the liquid solder and the base metal diffused, forming a diffusion layer. The post-weld heat treatment enhanced the diffusion of elements and effectively promoted the metallurgical bonding reaction between the filler metal and the base metal [20]. 

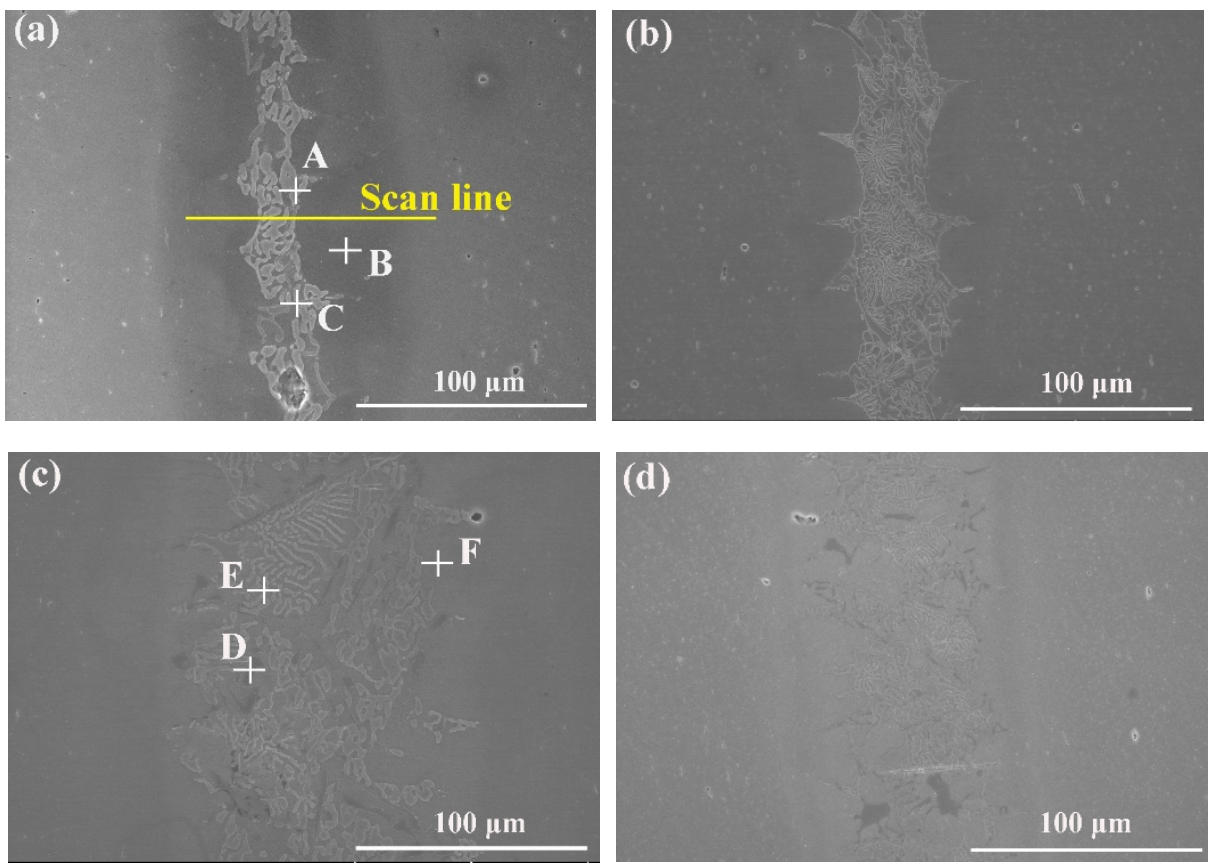

Figure 9. Microstructures of the (a) Al-6.5Si-20Cu, (b) Al-6.5Si-20Cu-1.0Ni, (c) Al-6.5Si-20Cu-1.5Ni, and (d) Al-6.5Si-20Cu-2.0Ni joints after brazing at $570{ }^{\circ} \mathrm{C}$ for $10 \mathrm{~min}$.

Table 6. Chemical composition (wt.\%) of the points in Figure 9.

\begin{tabular}{cccccc}
\hline Testing Points & Al & Si & Cu & Ni & Mg \\
\hline A & 49.04 & 0.85 & 49.76 & 0 & 0.35 \\
B & 96.46 & 0.62 & 2.61 & 0 & 0.30 \\
C & 34.12 & 61.89 & 3.99 & 0 & 0 \\
D & 23.67 & 74.83 & 1.07 & 0.29 & 0.15 \\
E & 59.95 & 0.85 & 29.83 & 9.37 & 0 \\
F & 90.59 & 2.51 & 6.59 & 0.31 & 0 \\
\hline
\end{tabular}

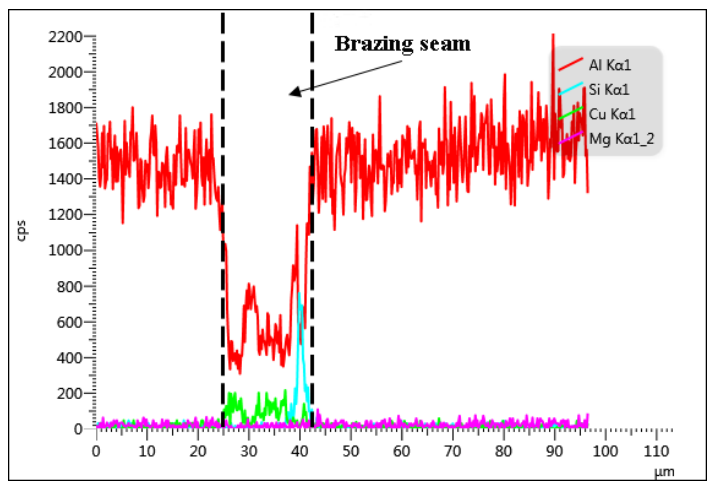

Figure 10. Elemental line scanning results for Figure 9a.

Figure 12a shows that the shear strength of the Al-6.5Si-20Cu brazed joint was approximately 117.2 MPa, and the shear strength of the Al-6.5Si-20Cu-(1.0, 1.5, 2.0) Ni brazed joints gradually increased with the increase in Ni content to $123.6 \mathrm{MPa}, 136.3 \mathrm{MPa}$, and $150.4 \mathrm{MPa}$, compared with the Al-6.5Si-20Cu brazed joints whose shear strength increased by $5.46 \%$, $16.30 \%$, and $28.32 \%$, respectively. Compared with the joint shear strength $(62.6 \mathrm{MPa}) \mathrm{ob}-$ tained by brazing 6063 aluminum alloy with the Al-8.5Si-25Cu-1.5Ni-0.2Re filler metal studied by Zhang et al. [5], the shear strength $(136.3 \mathrm{MPa})$ of the joint brazed with the Al6.5Si-20Cu-1.5Ni filler metal developed in this experiment increased by $117.73 \%$. Figure $12 \mathrm{~b}$ 
shows the microhardness curve of the brazed joints. There were $\mathrm{Al}_{2} \mathrm{Cu}$ intermetallic compounds and primary $\mathrm{Si}$ in the brazed seam center area of the weld $[2,7,25]$, and the hardness of this zone was $281 \sim 310 \mathrm{HV}$. During the brazing process, the elements between the filler metal and the base metal diffused to form a diffusion zone whose hardness was slightly higher than that of the base metal. The hardness of the interface area of the brazed seam was 107 216 HV, and the hardness of the base metal was 102 105 HV. Therefore, the microhardness of the brazing seam appears to decrease from the brazed seam center area to the base metal.
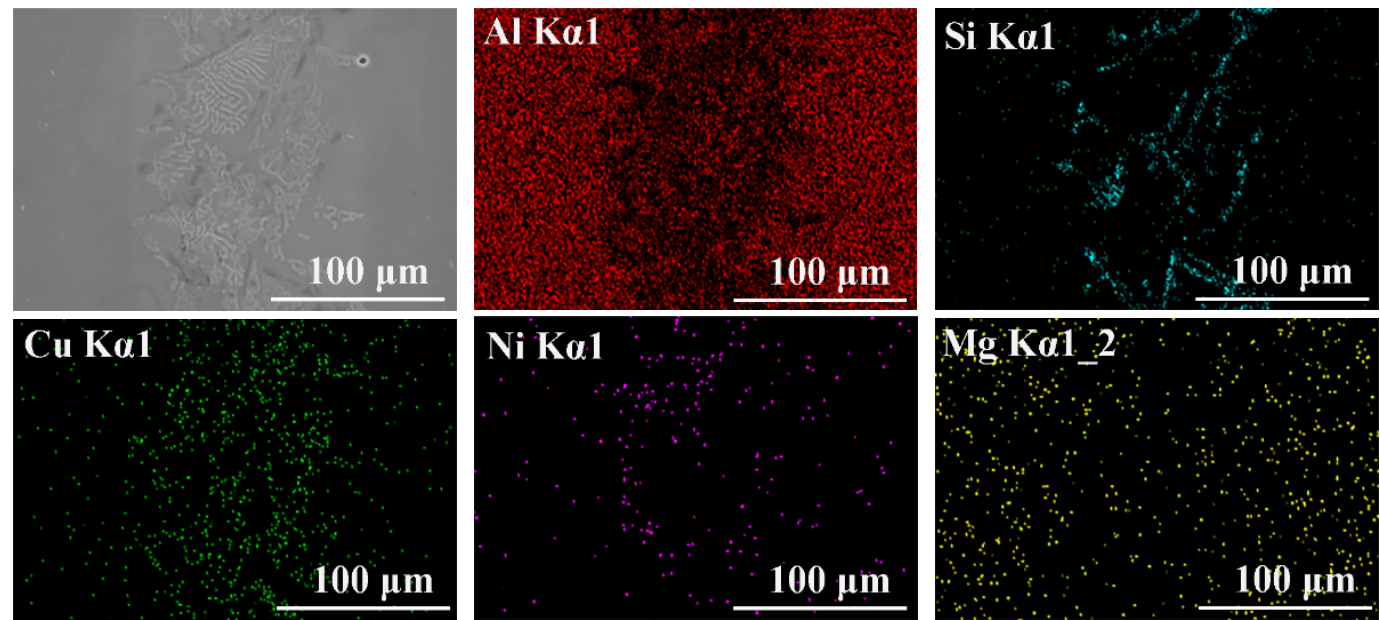

Figure 11. Element mapping of the 6063 aluminum alloy joint brazed with Al-6.5Si-20Cu-1.5Ni filler metal at $570{ }^{\circ} \mathrm{C}$ for $10 \mathrm{~min}$.
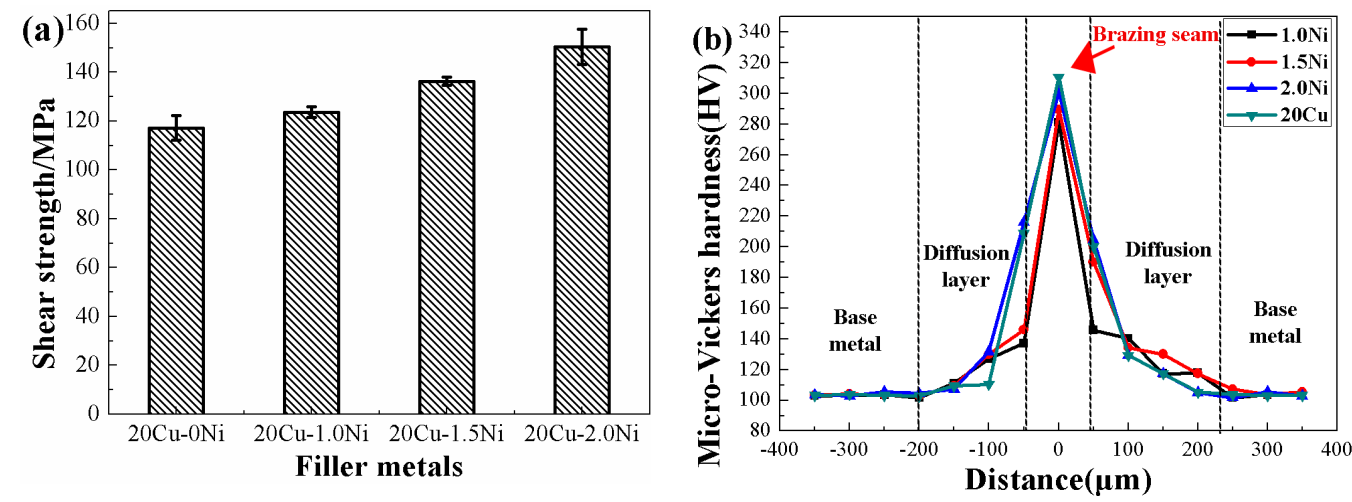

Figure 12. (a) Shear strength of 6063 aluminum alloy joints after brazing with Al-Si-Cu (Ni) filler metals at $570{ }^{\circ} \mathrm{C}$ for $10 \mathrm{~min}$. (b) Microhardness of the brazed joints.

Figure 13 shows the shear fracture morphology of 6063 aluminum alloy joints brazed with Al-Si-20Cu and Al-6.5Si-20Cu-(1.0, 1.5, 2.0) Ni filler metals. The fracture morphology of the brazed joints indicates the characteristics of brittle fracture. Table 7 lists the results of the EDS analysis of the typical phases of the fracture morphology of Al-Si-Cu (Ni) brazing joints. The results show that $\mathrm{A}, \mathrm{B}$, and $\mathrm{C}$ were the primary Si phase, the $\theta\left(\mathrm{Al}_{2} \mathrm{Cu}\right)$ phase, and the $\theta\left(\mathrm{Al}_{2} \mathrm{Cu}\right)+\delta\left(\mathrm{Al}_{3} \mathrm{Ni}_{2}\right)$ phase, respectively. In the process of brazing, elements in the matrix and liquid filler metal inter-diffused, so that the filler metal and the base metal had a better metallurgical bond. A small amount of $\mathrm{Mg}$ was detected in the joint fracture, so it can be judged that the fracture location of the brazed joint was roughly in the interface area of the brazed seam.

Based on the analysis of the microstructure, shear strength, and shear fracture morphology of the joint, when Al-6.5Si-20Cu brazed the 6063 aluminum alloy, there was a large $\theta\left(\mathrm{Al}_{2} \mathrm{Cu}\right)$ brittle phase in the brazing seam, but the large $\theta\left(\mathrm{Al}_{2} \mathrm{Cu}\right)$ phase had poor compatibility with the substrate deformation, the strain was concentrated at the phase 
interface, the crack initiation near the $\theta\left(\mathrm{Al}_{2} \mathrm{Cu}\right)$ phase was accelerated, and the fracture of the welded joint was accelerated, so the shear fracture of the brazed joint was a smooth and typical brittle fracture. When 6063 aluminum alloy was brazed with the Al-6.5Si-20Cu-Ni filler metal, the existence of $\mathrm{Ni}$ not only made the brittle phase of the $\mathrm{Al}_{2} \mathrm{Cu}$ finer and more dispersed but also improved the deformation coordination of the $\theta\left(\mathrm{Al}_{2} \mathrm{Cu}\right)$ phase and matrix and the shear strength of the brazed joint, reduced the strain concentration degree, and presented a mixed fracture mode.
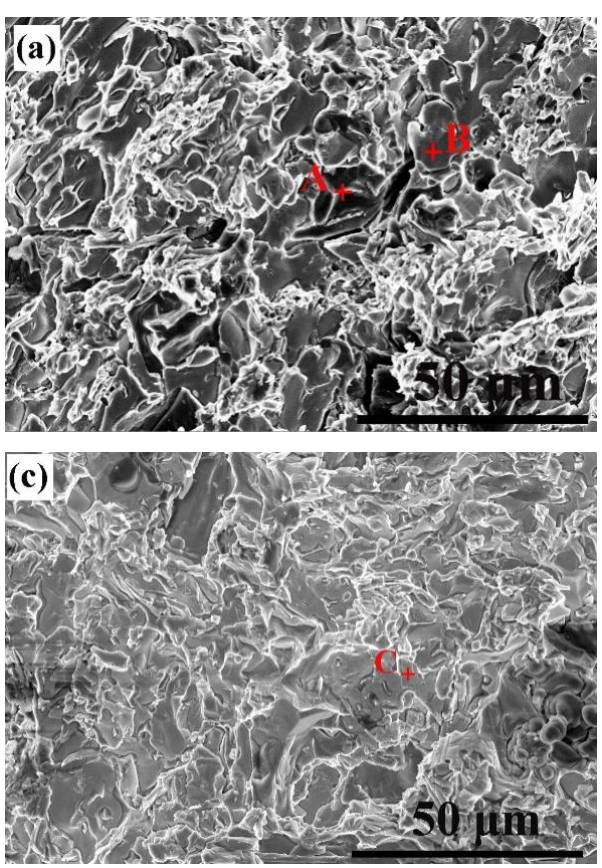
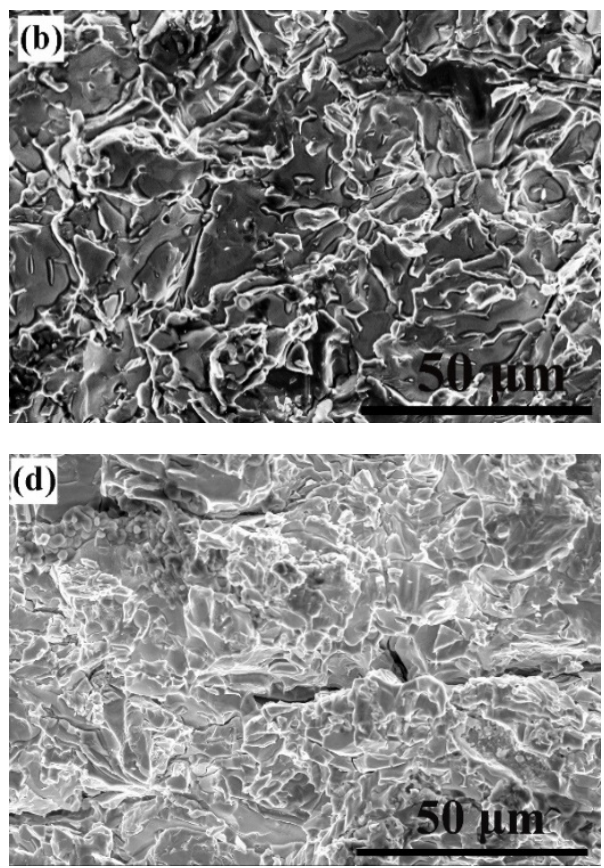

Figure 13. Shear fractographs of the 6063 aluminum alloy joints brazed with (a) Al-Si-20Cu, (b) AlSi-20Cu-1.0Ni, (c) Al-Si-20Cu-1.5Ni, and (d) Al-Si-20Cu-2.0Ni filler metals.

Table 7. Chemical composition (wt.\%) of the points in Figure 13.

\begin{tabular}{cccccc}
\hline Points & Al & Si & Cu & Ni & Mg \\
\hline A & 5.06 & 92.79 & 2.08 & 0 & 0.06 \\
B & 43.70 & 0.94 & 54.68 & 0 & 0.67 \\
C & 40.66 & 1.42 & 55.12 & 1.74 & 1.05 \\
\hline
\end{tabular}

\section{Conclusions}

In this paper, a new low-melting-point Al-Si-Cu (Ni) filler metal was designed and prepared. The melting characteristics, microstructure, and spreading wettability of the filler metal were researched and the microstructure and mechanical properties of the joint brazed with 6063 aluminum alloy were studied. The conclusions can be summarized as follows:

(1) The Al-Si-Cu filler metal was mainly composed of $\alpha$-Al solid solution, a $\theta\left(\mathrm{Al}_{2} \mathrm{Cu}\right)$ intermetallic compound, and bulk primary $\mathrm{Si}$. With increasing $\mathrm{Cu}$, the melting temperature of the Al-Si-Cu filler metal decreased, the melting interval became narrower, and the spreading performance improved. The melting range of the Al-6.5Si-20Cu filler metal was $521.4 \sim 533.4^{\circ} \mathrm{C}$, and the spreading area per unit mass was $2.87 \mathrm{~cm}^{2}$.

(2) The Al-Si-Cu-Ni filler metal was mainly composed of $\alpha$-Al solid solution, a $\theta\left(\mathrm{Al}_{2} \mathrm{Cu}\right)$ intermetallic compound, bulk primary $\mathrm{Si}$, and a $\delta\left(\mathrm{Al}_{3} \mathrm{Ni}_{2}\right)$ intermetallic compound. The addition of $\mathrm{Ni}$ not only narrowed the melting range of the Al-Si-Cu filler metal but also transformed the coarse, brittle $\mathrm{Al}_{2} \mathrm{Cu}$ phase from a bulk to a lamellar-type structure, and the structure was refined. With increasing Ni content, the spreading ability of the Al-Si-Cu-Ni filler metal decreased. The melting ranges of the Al-Si-Cu-Ni solder were $8.6^{\circ} \mathrm{C}, 7.7^{\circ} \mathrm{C}$, 
and $7.6^{\circ} \mathrm{C}$, and the spreading areas per unit mass were $3.28 \mathrm{~cm}^{2}, 3.12 \mathrm{~cm}^{2}$, and $3.02 \mathrm{~cm}^{2}$, respectively.

(3) When Al-6.5Si-20Cu and Al-6.5Si-20Cu-(1.0, 1.5, 2.0) Ni filler metals were used to braze 6063 aluminum alloy at $570{ }^{\circ} \mathrm{C}$ for $10 \mathrm{~min}$, brazing joints with shear strengths of 117.2 MPa, 123.6 MPa, 136.3 MPa, and 150.4 MPa were obtained. Therefore, the addition of $\mathrm{Ni}$ can effectively increase the shear strength of the brazed joints.

Author Contributions: Conceptualization, C.P. and F.Z.; methodology, C.P. and F.Z.; software, C.P. and F.Z.; validation, C.P., F.Z., and X.D.; formal analysis, C.P. and F.Z.; investigation, D.Z. and K.L.; resources, M.W. and Y.T.; data curation, C.P. and X.D.; writing—original draft preparation, C.P.; writing-review and editing, C.P.; visualization, X.D.; supervision, D.Z. and K.L.; project administration, M.W. and Y.T.; funding acquisition, F.Z. All authors have read and agreed to the published version of the manuscript.

Funding: This research was funded by the key special project of "Science and Technology Boost Economy 2020" of the Ministry of Science and Technology of China and the Science and Technology Program of Guizhou Province with Grant Nos. 20194106 and 20165654, 2021109.

Institutional Review Board Statement: Not applicable.

Informed Consent Statement: Not applicable.

Data Availability Statement: Not applicable.

Conflicts of Interest: The authors declare no conflict of interest.

\section{References}

1. Niu, Z.; Huang, J.; Liu, K.; Xu, F.; Chen, S.; Zhao, X. Brazing of 6061 aluminum alloy with the novel Al-Si-Ge-Zn filler metal. Mater. Lett. 2016, 179, 47-51. [CrossRef]

2. Pei, C.; Wu, X.; Zhang, G.; Cheng, Y.; Ren, X.; Wang, W.; Xiong, H. Microstructures and mechanical properties of brazed 6063 aluminum alloy joint with Al-Cu-Si-Ni filler metal. Weld. World 2020, 64, 1933-1938. [CrossRef]

3. Simões, S. Diffusion Bonding and Brazing of Advanced Materials. Matals 2018, 8, 959. [CrossRef]

4. Luo, W.; Wang, L.T.; Wang, Q.M.; Gong, H.L.; Yan, M. A new filler metal with low contents of Cu for high strength aluminum alloy brazed joints. Mater. Des. 2014, 63, 263-269. [CrossRef]

5. Zhang, G.; Bao, Y.; Jiang, Y.; Zhu, H. Microstructure and Mechanical Properties of 6063 Aluminum Alloy Brazed Joints with Al-Si-Cu-Ni-RE Filler Metal. J. Mater. Eng. Perform. 2011, 20, 1451-1456. [CrossRef]

6. $\quad$ Lacaze, J.; Tierce, S.; Lafont, M.C.; Thébault, Y.; Pébère, N.; Mankowski, G.; Blanc, C.; Robidou, H.; Vaumousse, D.; Daloz, D. Study of the microstructure resulting from brazed aluminium materials used in heat exchangers. Mater. Sci. Eng. A 2005, 413, 317-321. [CrossRef]

7. Chang, S.Y.; Tsao, L.C.; Li, T.Y.; Chuang, T.H. Joining 6061 aluminum alloy with Al-Si-Cu filler metals. J. Alloy. Compd. 2009, 488, 174-180. [CrossRef]

8. Dai, W.; Xue, S.; Lou, J.; Wang, S. Development of Al-Si-Zn-Sr filler metals for brazing 6061 aluminum alloy. Mater. Des. 2012, 42, 395-402. [CrossRef]

9. Wei, D.; Songbai, X.; Bo, S.; Jiang, L.; Suiqing, W. Study on Microstructure of 6061 Aluminum Alloy Brazed with Al-Si-Zn Filler Metals Bearing Sr and Ti. Rare Met. Mater. Eng. 2013, 42, 2442-2446. [CrossRef]

10. Niu, Z.W.; Huang, J.H.; Chen, S.H.; Zhao, X.K. Effects of germanium additions on microstructures and properties of Al-Si filler metals for brazing aluminum. Trans. Nonferrous Met. Soc. China 2016, 26, 775-782. [CrossRef]

11. Dai, W.; Xue, S.B.; Ji, F.; Lou, J.; Sun, B.; Wang, S.Q. Brazing 6061 aluminum alloy with Al-Si-Zn filler metals containing Sr. Int. J. Miner. Metall. Mater. 2013, 20, 365-370. [CrossRef]

12. Hayes, F.H.; Longbottom, R.D.; Ahmad, E.; Chen, G. On the Al-Si, Al-Ge, and Al-Ge-Si systems and their application to brazing in high power semiconductor devices. J. Phase Equilibria 1993, 14, 425-431. [CrossRef]

13. Suzuki, K.; Kagayama, M.; Takeuchi, Y. Eutectic phase equilibrium of Al-Si-Zn system and its applicability for lower temperature brazing. J. Jpn. Inst. Light Met. 1993, 43, 533-538. [CrossRef]

14. Gao, Z.; Ba, X.; Yang, H.; Yin, C.; Liu, S.; Niu, J.; Brnic, J. Joining of Silicon Particle-Reinforced Aluminum Matrix Composites to Kovar Alloys Using Active Melt-Spun Ribbons in Vacuum Conditions. Materials 2020, 13, 2965. [CrossRef] [PubMed]

15. Mondolfo, L.F. Aluminum Alloys: Structure and Properties; Butterworths: London, UK, 1976; pp. 509-511, 513-515.

16. Raghavan, V. Al-Cu-Si (Aluminum-Copper-Silicon). J. Phase Equilibria Diffus. 2007, 28, 180-182. [CrossRef]

17. Murray, J.L. The aluminium-copper system. Int. Mater. Rev. 1985, 30, 211-234. [CrossRef]

18. Murray, J.L. The Al-Si (Aluminum-Silicon) system. Bull. Alloy. Phase Diagr. 1984, 5, 84. [CrossRef]

19. Garbellini, O.; Palacio, H.; Biloni, H. Correlation between Fluidity and Solidification-Microstructures at the Aluminium-rich Corner of the Al-Cu-Si System. Cast Met. 1990, 3, 82-90. [CrossRef] 
20. Xue, J.Y.; Yuan-Xing, L.I.; Chen, H.; Zhu, Z.T. Wettability, microstructure and properties of 6061 aluminum alloy/304 stainless steel butt joint achieved by laser-metal inert-gas hybrid welding-brazing. Trans. Nonferrous Met. Soc. China 2018, 28, $1938-1946$. [CrossRef]

21. Belov, N.A.; Eskin, D.G.; Avxentieva, N.N. Avxentieva, Constituent phase diagrams of the Al-Cu-Fe-Mg-Ni-Si system and their application to the analysis of aluminium piston alloys. Acta Mater. 2005, 53, 4709-4722. [CrossRef]

22. Farkoosh, A.R.; Javidani, M.; Hoseini, M.; Larouche, D.; Pekguleryuz, M. Phase formation in as-solidified and heat-treated Al-Si-Cu-Mg-Ni alloys: Thermodynamic assessment and experimental investigation for alloy design. J. Alloy. Compd. 2013, 551, 596-606. [CrossRef]

23. Yang, L.; Li, W.; Du, J.; Wang, K.; Tang, P. Effect of Si and Ni contents on the fluidity of Al-Ni-Si alloys evaluated by using thermal analysis. Thermochim. Acta 2016, 645, 7-15. [CrossRef]

24. Yu, H.; Zhang, L.; Cai, F.; Zhong, S.; Ma, J.; Zhang, Y.; Si, A.; Wei, S.; Long, W.; Stock, H.R.; et al. Interface microstructure and growth mechanism of brazing Cu/Al joint with BAl88Si filler metal. Vacuum 2020, 181, 109641. [CrossRef]

25. Chuang, T.H.; Tsao, L.C.; Tsai, T.C.; Yeh, M.S.; Wu, C.S. Development of a Low-Melting-Point Filler Metal for Brazing Aluminum Alloys. Metall. Mater. Trans. A 2000, 31, 2239-2245. [CrossRef] 